\title{
Diabetes mellitus: knowledge and attitudes, collaborating for individual and social development of a reef community
}

\author{
Tereza Cristina Pinho Paes Barreto*, Amanda Pinho Paes Barreto, Joselí Reis, Rozângela Amorim Santos \\ From 20th Brazilian Diabetes Society Congress \\ Porto Alegre, Brazil. 11-18 November 2015
}

\section{Background}

The treatment of diabetes requires patient compliance, based on positive measures, inserted in social development.

\section{Objective}

To compare the level of knowledge and the psychological adjustment to diabetes mellitus users of the Family Health Unit.

\section{Method}

A prospective, cross-sectional, quantitative study, with comparison groups, carried out between June-August 2012 included 207 users of the Family Health Unit Finch Low, divided into three groups according to Results of glycated hemoglobin, analyzed by standard American Diabetes Association. The sample was divided into three groups as users were diabetic treated in the unit (group $\mathrm{A}=53$ ); newly diagnosed diabetics in the unit (group $\mathrm{B}=85$ ) and non-diabetic patients (group $\mathrm{C}=69$ ). The collection tools included demographic information, anthropometric and related to the disease, the questionnaire of knowledge about diabetes (DKN-A) and psychological and emotional attitudes towards disease (TA-19). As well as adherence to behaviors related to individual and social development. The variables were organized using SPSS version 17.0 software and analyzed with the Student t test, KolmogorovSmirnov and chi square, at 0.05 significance level.

\section{Results}

We diagnosed $41.06 \%$ of users as diabetic or pre-diabetic screening. Regardless of the group to which you belong, there was little knowledge about the disease, and negative

\footnotetext{
* Correspondence: terezapinho2006@yahoo.com.br

Pronto Socorro Cardiológico de Pernambuco, Recife, Brazil
}

psychological and emotional adaptation, pointing down user engagement to treatment.

\section{Conclusions}

changes are needed in health education focused on diabetes, enabling formation of social consciousness that will motivate positive behavioral changes to patients and to society in general.

Published: 11 November 2015

doi:10.1186/1758-5996-7-S1-A174

Cite this article as: Barreto et al:: Diabetes mellitus: knowledge and attitudes, collaborating for individual and social development of a reef community. Diabetology \& Metabolic Syndrome 2015 7(Suppl 1):A174.

Submit your next manuscript to BioMed Central and take full advantage of:

- Convenient online submission

- Thorough peer review

- No space constraints or color figure charges

- Immediate publication on acceptance

- Inclusion in PubMed, CAS, Scopus and Google Scholar

- Research which is freely available for redistribution

Submit your manuscript at www.biomedcentral.com/submit 